\title{
馬精液の凍結保存に関する研究
}

\section{III. 液体窒素で保存した錠剤化凍結精液による受胎成績}

\author{
押田 等 · 三川・武・堀内精司・高橋裕郎 \\ （福島県いわき家甾保健衛生所）（ホクレン北見支所） \\ 富塚常夫・永瀬 弘 \\ （農林省畜産試験場）
}

著者ら ${ }^{1 \sim 3)}$ は牛精液で得られた成績から, いわゆる錠 剂化凍結法が馬精液にも適用できる可能性を䜑め, 1963 年馬の錠剤化凍結精液による受胎に成功して以来一連の 試験研究を行なってきた ${ }^{4,5)}$ 。

従来, 著者らが行なった試験はドライアイスを使用し たもので，その受胎率は $33.3 \%(12.5 〜 47.3 \%-1965$ 年の成績 $)^{5)}$ であった。

牛精液の凍結保存には, 最近寒郕として液体窒素が広 く使用されてきており, 精液の取扱い, 寒郕の補給, 長 期保存における生存成績などの点で有利であるとされて いる。

この試験は，馬の錠剂化凍結精液の保存に従来のドラ イアイスに代えて液体窒素を使用したさい，どの程度の 受胎率が得られるかを知るため行なわれた。

従来液体窒素を利用した馬精液の凍結に関する正式な 報告は皆無に近い状態である。

ただ， 1965 年の A.I. Digest の記事6) およびデン マークの $\mathrm{WIBLING}^{7)}$ の成績があるのみである。WIBLING の永瀬への私信によれば, 1966年春, 錠剤化凍結法を馬 精液に試み, 授精 10 頭中 7 頭に受胎を見た由である。 この 2 つ成績は実施頭数が極く少数で, 実験室的研究 の域を出ていないと言える。

Studies on the freezing storage of stallion semen. III. Freezing of pellet frozen semen preserved in liquid nitrogen.

Oshida, Hitoshi, Takeshi Mikawa (Iwaki Livestock Hygien Service Center, Fukushima Prefecture), Seishi Horiuchi, H. Takahashi, (Hokuren, Kitami Division, Kitami, Hokkaido), Tsuneo Tomizuka \& Hiroshi NAGASE (National Institute of Animal Industry, Chiba-shi)

Jap. J. Animal Reprod. 13 (4), 1967.
著者らが，1966 年春に行なったこの試験は，9 頭の 雄馬の精液を野外のいわゆる routine work の条件下 で, 100 頭に近い雌馬に授精したもので, この分野の研 究資料の少ない現在かなり貴重な資料になるものと思わ れる。

この試験の間, 精子の耐凍性などについても 1,2 の 知見を得たが，ここではとりあえず受胎成績のみを取纏 め速報の意味で発表する。

\section{試験方法}

\section{1）供用馬}

雄馬は朝鮮馬, 北海道在来馬各 1, ペルシュロンおよ びその雑種 3 , ブルトン種 4 の計 9 頭で, 授精対象雌 馬は試験地近傍の農馬で，とくに制約を設けず，発情の 判定も外部徵候により, 発情中の卵巣検査は北見地区の 1 名を除いて実施しなかった。

2）実施地域，期間

福島県いわき市および北海道北見市を中心とする $2 つ$ の地区で実施した。精液の採取, 凍結は北見地区では 3 月中旬, 福島地区では 2〜6 月にわたり, 雄馬を繫養し ている現地で行ない，そのまま液体窒素中に保存し 4〜 7 月の間授精に使用した。授精師数は北見地区 4 名, 福 島地区 3 名計 7 名である。

3）精液の処理, 凍結

精液の処理, 凍結の要領は前報に準じ5) たが, 保存に 液体窒素を用いまた $5^{\circ} \mathrm{C}$ までの泠却を下記のように変 更した。すなわち, 遠沈で濃縮後, 希釈された精液を小 試験管に移し，これを水を入れないビーカー中に立て， そのまま $5^{\circ} \mathrm{C}$ の恒温器中に静置して冷却した。また液 体窒素中に保存するための錠剂精液の容器は, プラスチ ック製の小試験管（径 $1 \mathrm{c} \mathrm{m}$, 長さ $3 \sim 5 \mathrm{~cm}$ ) を用い, 
これに錠郕精液 5２0 錠を入れ，ゴム栓またはプラス チックフィルムの加熱シールを行なった後, 液体窒素中 に保存した。

4) 授精

保存精液の農家までの運搬はドライアイス中で行ない 授精は融解直後に実施した。

北見地区では錠剤精液の融解を特製のステンレススチ ールの試験管内で行なった後, 融解液と混合した。

凍結精液の使用は原則として一発情のみに止め, 以後 の発情には自然交配を行なった。

一発情中の授精回数は 1 3 回で, 結果の判定は直腸 検査法によった。

\section{結果ならびに考察}

北見，福島両地区における雄馬別の受胎成績を表 1 に 示した。

両地区の合計では，93 頭に授精して 43 頭に受胎が 認められ，この内，結果の不明であった 1 頭を除くと受 胎率は $46.7 \%$ (43/92) となった。これを昨年のドライ アイスを用いた受胎成績 $33.3 \%(14 / 42)$ と比較すると かなり良好であったが，この試験で行なった程度の保存 期間で両者の受胎率に本質的な差があるかどうかは今後 の厳密な比較に俟たなければならない。

外国における受胎成績は，A.I. Digest の記事，
WIBLING とも $70 \%$ 台を示しており，著者らの成績とは かなりの差異が見られるが，これは恐らく授精対象の雌 馬の選定基準の差によるものと考えられる。

福島，北見両地区の成績は，それぞれ $47.1 ， 46.3 \%$ でほぼ同じであった。北見地区は最初の試みで，人工授 精センターの技術者, 授精師とも凍結精液の取扱いは未 経験であった事実を考慮すると，かなり良好な成績と言 えると思う。

雄馬別の受胎成績を見ると $22.2 \%$ から $66.7 \%$ とかな り大きな差異が認められるが，この程度の授精頭数では 雌馬の発情状態などがかなり影響を持っているものと思 われる。

いま，精液性状の明らかな福島地区における受胎成績 を個体別に示すと表 2４９通りで，受胎例における精 液の保存日数の範囲は 1〜110 日, 同じく錠剂数 3〜11, 精子生存率は 15～65\%，注入精子数は 3.63〜31.24× 108) であった。

いま注入精子数と受胎率の関係を見ると，精子数 3〜 4 億台で 50\% (2/4)，5～6 億台で 50\% (5/10)，7〜 8 億台で $76.4 \%$ (10/13), 9～10 億台では 50\% (1/2), 13〜14 億台で $42.8 \%(3 / 7)$ となり，7～8 億台の注入 精子が最良の成績を示した。授精の例数が少ないので今 後追試する必要があるのは勿論であるが，この数字は雌 馬の発情，注入の条件が良好であれば， 7〜8 億台の精

Table 1. Fertility of pellet frozen stallion semen preserved in liquid nitrogen

(Mar. July, 1966)

\begin{tabular}{|c|c|c|c|c|c|}
\hline Area & Breed & Name of stallion & $\begin{array}{c}\text { No. of mares } \\
\text { inseminated }\end{array}$ & $\begin{array}{l}\text { No. of mares } \\
\text { concepted }\end{array}$ & Conception rates \\
\hline \multirow{4}{*}{ Fukushima } & Percheron & G. K. & 18 & 12 & $66.7 \%$ \\
\hline & \multirow{2}{*}{ Pony } & K. S. & 10 & 4 & 40.0 \\
\hline & & $\mathrm{K} . \mathrm{K}$. & 23 & 8 & 34.8 \\
\hline & Total & 3 & 51 & 24 & 47.1 \\
\hline \multirow{7}{*}{ Kitami } & \multirow{2}{*}{ Percheron } & O. S. & 7 & 2 & 28.6 \\
\hline & & E. R. & 9 & 5 & 55.6 \\
\hline & \multirow{4}{*}{ Breton } & R. Z. & 8 & 5 & 62.5 \\
\hline & & K. R. & 8 & 4 & $57.1(4 / 7) *$ \\
\hline & & H. K. & 9 & 2 & 22.2 \\
\hline & & N. L. & 1 & 1 & 100.0 \\
\hline & Total & 6 & 42 & 19 & $46.3(19.41) *$ \\
\hline Both areas & Total & 9 & 93 & 43 & 46. $7(43 / 92) *$ \\
\hline
\end{tabular}

* Except one mare which was not able to know the result.

Conception rates were indicated results on one-heat inseminations 
Table 2. Semen conditions and the results in Fukushima trial No. 1 G.K. (Percheron stallion)

Conception rates $\cdots 66.7 \%(12 / 18)$ (one heat-inseminations)

\begin{tabular}{|c|c|c|c|c|c|c|c|c|c|c|}
\hline \multirow{2}{*}{$\begin{array}{l}\text { No. of } \\
\text { mares }\end{array}$} & \multirow{2}{*}{$\begin{array}{l}\text { Years of } \\
\text { mare }\end{array}$} & \multicolumn{2}{|c|}{ Date } & \multirow{2}{*}{$\begin{array}{l}\text { Storage } \\
\text { (days) }\end{array}$} & \multirow{2}{*}{$\begin{array}{l}\text { No. of } \\
\text { pellet } \\
\text { insemi- } \\
\text { nated }\end{array}$} & \multirow{2}{*}{$\begin{array}{l}\text { No. of } \\
\text { sperm } \\
\text { insemi- } \\
\text { nated }\end{array}$} & \multirow{2}{*}{$\begin{array}{c}\text { Survival } \\
\text { rates of } \\
\text { the sperm }\end{array}$} & \multirow{2}{*}{$\mid \begin{array}{c}\text { No. of } \\
\text { living spm. } \\
\text { insemi- } \\
\text { nated }^{*}\end{array}$} & \multirow{2}{*}{\multicolumn{2}{|c|}{ Results** }} \\
\hline & & Freezing & $\begin{array}{l}\text { Insemi- } \\
\text { nation }\end{array}$ & & & & & & & \\
\hline 1 & 10 & 16 Apr. & 21, 23 Apr. & $5 \& 7$ & $7 \& 8$ & $\begin{array}{r}\left(\times 10^{8}\right) \\
14,880\end{array}$ & $20 \%$ & $\begin{array}{c}\left(\times 10^{8}\right) \\
2,976\end{array}$ & + & \\
\hline 2 & 5 & 16 Apr. & 27 Apr. & 12 & 11 & 31,400 & 25 & 7,810 & + & - \\
\hline 3 & 8 & 16 Apr. & 31 May & 46 & 10 & 28,400 & 25 & 7,100 & + & - \\
\hline 4 & 7 & 12 Jun. & 12 Jun. & $1>$ & 8 & 8,192 & 60 & 4,915 & + & - \\
\hline 5 & 10 & 12 Jun. & 26 Jun. & 14 & 7 & 7,168 & 60 & 4,301 & + & • \\
\hline 6 & 10 & 16 Apr. & 16 May & 31 & 8 & 14,880 & 20 & 2,976 & + & • \\
\hline 7 & 12 & 22 July & $25,26 \mathrm{July}$ & $4 \& 4$ & $7 \& 7$ & 23,226 & 15 & 3,484 & + & \\
\hline 8 & 13 & 12 Jun. & 12 Jun. & $1>$ & 8 & 8,192 & 60 & 4,915 & + & - \\
\hline 9 & 7 & 22 July & 23 July & 1 & 8 & 19,840 & 25 & 4,960 & + & - \\
\hline 10 & 8 & 11 Jun. & 11 Jun. & $1>$ & $7 \& 7$ & 5,634 & 65 & 3,662 & + & • \\
\hline 11 & 19 & 11 Jun. & 25 Jun. & 14 & 6 & 5,568 & 65 & 3,619 & + & \\
\hline 12 & 11 & 12 Jun. & 12 Jun. & $1>$ & 8 & 8,192 & 60 & 4,915 & + & - \\
\hline 13 & 11 & $\begin{array}{l}11 \text { Jun. } \\
15 \text { Apr. }\end{array}$ & 26, 28 Jun. & $15 \& 75$ & $8 \& 6$ & 20,808 & 45 & 9,364 & - & \\
\hline 14 & 3 & 16 Apr. & 23 May & 38 & 10 & 28,400 & 25 & 7,100 & - & \\
\hline 15 & 4 & 11 Jun. & 11 Jun. & $1>$ & 7 & 5,634 & 65 & 3,662 & - & \\
\hline 16 & 5 & $\begin{array}{l}11 \text { Jun. } \\
15 \text { Apr. }\end{array}$ & 2, 3 July & $22 \& 80$ & $8 \& 8$ & 27,744 & 45 & 12,485 & - & - \\
\hline 17 & 11 & 11 Jun. & 14 Jun. & 3 & 5 & 4,640 & 65 & 3,016 & - & \\
\hline 18 & 9 & 15 Apr. & 23 Jun. & 70 & 7 & 24,276 & 45 & 10,924 & - & - \\
\hline
\end{tabular}

*: Calculated from survival rates and numbers of spermatozoa inseminated.

**: - With suckling foal, + Pregnant, - Non pregnant

Table 3. Semen conditions and the results in Fukushima trial No. 2 K.S. (Pony stallion)

Conception rates $\cdots 40.0 \%(4 / 10)$

\begin{tabular}{|c|c|c|c|c|c|c|c|c|c|}
\hline \multirow{2}{*}{$\begin{array}{c}\text { No. of } \\
\text { mares }\end{array}$} & \multirow{2}{*}{$\begin{array}{c}\text { Years of } \\
\text { mare }\end{array}$} & \multicolumn{2}{|c|}{ Date } & \multirow{2}{*}{$\begin{array}{l}\text { Storage } \\
\text { days }\end{array}$} & \multirow{2}{*}{$\begin{array}{l}\text { No. of } \\
\text { pellets } \\
\text { insemi- } \\
\text { nated }\end{array}$} & \multirow{2}{*}{$\begin{array}{l}\text { No. of } \\
\text { sperm } \\
\text { insemi- } \\
\text { nated }\end{array}$} & \multirow{2}{*}{$\mid \begin{array}{c}\text { Survival } \\
\text { rates of } \\
\text { the sperm }\end{array}$} & \multirow{2}{*}{$\left|\begin{array}{c}\text { No. of } \\
\text { living spm. } \\
\text { insemi- } \\
\text { nated }\end{array}\right|$} & \multirow{2}{*}{ Results } \\
\hline & & Freezing & $\begin{array}{l}\text { Insemi- } \\
\text { nation }\end{array}$ & & & & & & \\
\hline 1 & 16 & $6 \mathrm{Apr}$. & 4 May & 28 & 3 & 9,168 & $65 \%$ & $\begin{array}{l}\left(\times 10^{8}\right) \\
6,051\end{array}$ & + \\
\hline 2 & 6 & 31 Mar. & 23, 28 May & $52 \& 57$ & $6 \& 7$ & 13,058 & 65 & 8,486 & + \\
\hline 3 & 16 & $15 \mathrm{Feb}$. & 5 Jun. & 110 & 6 & & & & + \\
\hline 4 & 10 & $15 \mathrm{Feb}$. & 3 Jun. & 108 & 10 & & & & + \\
\hline 5 & 10 & 31 Mar. & 27, $28 \mathrm{Apr}$ & $27 \& 28$ & 7 & 15,232 & 65 & 9,901 & - \\
\hline 6 & 11 & 3 Mar. & 28 May & 54 & 7 & & & & - \\
\hline 7 & 10 & 28 Mar. & 31 May & 64 & 7 & 13,776 & 55 & 7,577 & - \\
\hline 8 & 7 & 28 Feb. & 6 Jun. & 99 & 7 & 13,776 & 55 & 7,577 & - \\
\hline 9 & 7 & $28 \mathrm{Feb}$ & 4 Jun. & 96 & 7 & 13,776 & 55 & 7,577 & - \\
\hline 10 & 17 & 28 Mar. & 28 Jun. & 92 & 5 & & 55 & & - \\
\hline
\end{tabular}


Table 4. Semen conditions and the results in Fukushima trial No. 3 K.Z.

Conception rates $\cdots 34.8 \%(8 / 23)$

\begin{tabular}{|c|c|c|c|c|c|c|c|c|c|c|}
\hline \multirow{2}{*}{$\begin{array}{c}\text { No. of } \\
\text { mare }\end{array}$} & \multirow{2}{*}{$\begin{array}{l}\text { Years of } \\
\text { mare }\end{array}$} & \multicolumn{2}{|c|}{ Date } & \multirow{2}{*}{$\begin{array}{c}\text { Storage } \\
\text { days }\end{array}$} & \multirow{2}{*}{$\begin{array}{c}\text { No. of } \\
\text { pellets } \\
\text { insemi- } \\
\text { nated }\end{array}$} & \multirow{2}{*}{$\begin{array}{l}\text { No. of } \\
\text { sperm } \\
\text { insemi- } \\
\text { nated }\end{array}$} & \multirow{2}{*}{$\begin{array}{l}\text { Survival } \\
\text { rates of } \\
\text { the sperm }\end{array}$} & \multirow{2}{*}{$\mid \begin{array}{c}\text { No. of } \\
\text { living spm. } \\
\text { insemi- } \\
\text { nated }\end{array}$} & \multirow{2}{*}{\multicolumn{2}{|c|}{ Results }} \\
\hline & & Freezing & $\begin{array}{l}\text { Insemi- } \\
\text { nation }\end{array}$ & & & & & & & \\
\hline 1 & 10 & 16 Apr. & 2 Jun. & 47 & 10 & $\begin{array}{c}\left(\times 10^{8}\right) \\
15,800\end{array}$ & $35 \%$ & $\begin{array}{c}\left(\times 10^{8}\right) \\
5,530\end{array}$ & + & \\
\hline 2 & 10 & 12 Jun. & 14 Jun. & 2 & 7 & 6,384 & 65 & 4,150 & + & • \\
\hline 3 & 12 & 12 Jun. & 14 Jun. & 2 & 7 & 6,384 & 65 & 4,150 & + & \\
\hline 4 & 8 & 22,23 July & 25,26 July & 3 & $7 \& 7$ & 20,720 & 15 & 3,108 & + & - \\
\hline 5 & 8 & 11 Jun. & 23 Jun. & 12 & 7 & 6,580 & 35 & 2,308 & + & \\
\hline 6 & 8 & 11,12 Jun. & $\begin{array}{r}28 \text { Jun. } \\
1 \text { July }\end{array}$ & $17 \& 20$ & $5 \& 8$ & 8,320 & 65 & 5,408 & + & - \\
\hline 7 & 10 & 11 Jun. & 30 Jun. & 19 & 5 & 4,700 & 35 & 1,645 & + & - \\
\hline 8 & 8 & 11 Jun. & 30 Jun. & 19 & 8 & 7,520 & 35 & 2,632 & + & \\
\hline 9 & 11 & 11 Jun. & 12 July & 30 & 7 & 2,576 & 55 & 1,417 & - & - \\
\hline 10 & 8 & 16 Apr. & 22, 23 Jun. & $66 \& 67$ & $5 \& 5$ & 18,400 & 45 & 8,280 & - & \\
\hline 11 & 9 & 16 Apr. & 2 Jun. & 52 & 8 & 7,520 & 35 & 2,632 & - & \\
\hline 12 & 10 & 12 Jun. & 14 Jun. & 2 & 6 & 5,472 & 65 & 3,557 & - & \\
\hline 13 & 10 & 12 Jun. & 14 Jun. & 3 & 6 & 5,472 & 65 & 3,557 & - & \\
\hline 14 & 13 & 16 Apr. & 2 Jun. & 47 & 11 & 17,380 & 35 & 6,083 & - & \\
\hline 15 & 10 & 11 Jun. & 12 July & 31 & 8 & 2,944 & 55 & 1,619 & - & \\
\hline 16 & 6 & 16 Apr. & 2 Jun. & 47 & 5 & 18,400 & 45 & 8,280 & - & \\
\hline 17 & 6 & 11 Jun. & 12 July & 31 & 7 & 6,580 & 35 & 2,303 & - & \\
\hline 18 & 7 & 11 Jun. & 14 Jun. & 3 & 5 & 1,840 & 55 & 1,012 & - & \\
\hline 19 & 6 & 12 Jun. & 14 Jun. & 2 & 5 & 4,560 & 65 & 2,964 & - & \\
\hline 20 & 10 & 11 Jun. & 21,23 Jun. & $10 \& 12$ & $5 \& 5$ & 18,400 & 45 & 8,280 & - & \\
\hline 21 & 4 & 11,16 Jun. & 21, 23 Jun. & $10 \& 18$ & $6 \& 5$ & 18,400 & 45 & 8,280 & - & \\
\hline 22 & 9 & 11 Jun. & 30 Jun. & 19 & 10 & 9,400 & 35 & 3,290 & - & \\
\hline 23 & 5 & 12 Jun. & 12 July & 24 & 6 & 6,240 & 65 & 4,056 & - & \\
\hline
\end{tabular}

子の注入で十分であることを示していると思われる。

保存日数と受胎率の関係では，1３0日-56.2\%（18/ 32), 31〜60日-36. $0 \%(9 / 25), 61 \sim 90$ 日-35.2\%(6/17), 91〜110日ー $57.1 \%(4 / 7)$ の成績が得られた。また本試 験では, 従来受胎しがたいと言われている哺乳中の, い わゆる子付の雌馬でも, かなりの受胎率が得られた。

\section{摘 要}

液体窒素で保存した馬の錠剂化凍結精液による授精試 験を実施した。

1) 雄馬 9 頭（重種 3, 中間種 4, ポニー2）を用 い, 希釈精液の $0.2 \mathrm{~m} l$ をドライアイス上で錠剤化凍結 を行なった後液体窒素中で保存した。農家までの凍結精 液の運搬はドライアイス中で行ない, 融解直後に注入し た。対象の雌馬は特に制約を設けなかった。

2) 授精頭数は 93 頭で, この内 43 頭が受胎し, 受
胎率は $46.7 \%$ (不明一頭を除く)であった。

3）受胎例における精液性状の範囲は，精子数では， 3. 63 31. 24 億で, 精子生存率は 15 65\%, 注入錠剤 数は 3〜11, 保存日数は 1〜110 日であった。注入精子 数と受胎率の関係では，7～8 億台の受胎率が $76.9 \%$ (10/13) で最も良好であった。

この試験を実施するに当って格別のご援助を頂いた農 林省畜産試験場繁殖部長細田達雄博士, 日本軽種馬登録 協会副会長早田伝之助氏，ホクレン参事守屋喜義氏，同 訓子府家畜改良牧場長後藤美城氏ならびに授精を直接担 当された福島県いわき家畜保健衛生所の相良, 星, 横井 各技師, ホクレン北見支所管内, 西川, 岡田, 松原, 大 西の各氏に対し禹心より感謝の意を表する。

(1967. 6. 21 受付) 


\section{文献}

1) 永瀬（弘) - 丹羽 (太) - 本誌, 9, 73, 1963. 2) Nagase, H. \& E.F. Graham: Proceed. Vth Intern. Congr. Anim. Reprod. \& A.I., 4, 387, 1964. 3) Nagase, H., E.F. Graham \& T. Niwa: Proceed. Vth Intern. Congr. Anin. Reprod. \& A.I., 4, 404, 1964.
4) 永瀬 (弘) ・ 副島 (昭) -丹羽 (太) - 押田 (等), 相 良 (芳) - 石埼 (信) - 星 (栄) - 本誌, 12, 48, 1966.

5) 永瀬 (弘) - 副島 (昭) - 富塚 (常) - 押田 (等) - 三 川 (武) - 相良 (芳) - 星 (栄) - 丹羽 (太) - 本誌, 12, 52, 1966. 6) A.I. Digest, 13, (No. 11), 12, 1965. 7) Wibling,H.：永瀬一の私信。

\section{Summary}

Fertility trials using pellet frozen stallion semen preserved in liquid nitrogen were conducted in 1966.

Semen, collected from 9 stallions (Percheron 3, Breton 4, Pony 2) with gel portion removed, was extended 1:1 with yolk (5 parts) $-5 \%$ glucose (95 parts) solution and then centrifuged at $1,300 \mathrm{~g}, 20$ min. for concentrate of semen.

The concentrated semen had the supernatant removed and was extended again 1:2 3 with yolksugar-glycerol extender, which was composed of 10 parts of egg-yolk, 5.5 parts of glycerol and 84.5 parts of sugar media (glucose $1.8 \mathrm{gm}$, lactose $4.4 \mathrm{gm}$, raffinose $5.4 \mathrm{gm}$ in $100 \mathrm{~m} l$ ).

The extended semen was cooled to $5^{\circ} \mathrm{C}$ at semi-rapid rate by keeping it in small test tubes which were kept standing directly in $5^{\circ} \mathrm{C}$ cold air room. The $0.2 \mathrm{ml}$ of the cooled semen was placed directly on a block of dry ice after $2 \sim 3$ hours of glycerol equilibration.

Semen frozen in pellet form on dry ice was transfered into plastic tubes (diameter $1.2 \mathrm{~cm}$, height $5.0 \mathrm{~cm}$ ) which were made to stand in holes made in dry ice. Then the plastic tubes were sealed with plastic-aluminum film using the electric heat sealer. The small plastic tubes were stored in liquid nitrogen until use.

The frozen semen was carried to the mares owned by farmers in crushed dry ice by A. I. technicians.

Inseminations were carried out immediately after thawing, in which the 5-20 pellets of semen were added to $20 \mathrm{~m} l$ of the thawing media in ampoules kept at $30 \sim 35^{\circ} \mathrm{C}$.

The thawing media were a mixture of following solutions and were stored at $4^{\circ} \mathrm{C}$ or at room temperature after heating repeatedly in ampoules. 1) Skim milk $100 \mathrm{~m} l$. 2) Buffer solution $77.0 \mathrm{~m} l$. Composed of; Sod. citrate $1.57 \mathrm{gm}$, Sod. carbonate $0.075 \mathrm{gm}$, Pot. carbonate $0.085 \mathrm{gm}$, Glucose $2.7 \mathrm{gm}$, P-aminomethylbenzensulfonamide $0.2 \mathrm{gm}$, Distilled water up to $100 \mathrm{~m} l$. 3) Glycerol $3.0 \mathrm{~m} l$. The pH of the mixed media $\cdots 7.0$ (adjusted by $5.5 \%$ citric acid solution).

The mares were inseminated 1 3 times per heat under conditions of the routine work and diagnoses to determine conceptions were performed by the rectal palpation. Inseminations to 93 mares, each of which was inseminated only during one heat, resulted in 43 conceptions. Fertility was 46.7 per cent, except one mare for which we could not know the result (Table 1).

Semen conditions in successful inseminations were as follows;

Storage period $\cdots 1 \sim 110$ days, Survival rates of sperm $\cdots 15-65 \%$, No. of pellets inseminated $\cdots$

$3-11$, No. of sperms inseminated $\cdots 3.63-31.24\left(\times 10^{8}\right)$.

Relationships of no. of spermatozoa inseminated and conceptions were as follows; $3 \sim 4\left(\times 10^{9}\right) \cdots$ $50 \%(2 / 4), 5 \sim 6 \cdots 50 \%(5 / 10), 7 \sim 8 \cdots 76.9 \%(10 / 13), 9 \sim 10 \cdots 50 \%(1 / 2), 13 \sim 14 \cdots 42.8 \%(3 / 7)$.

Although the number of mares was too small and further observations should be needed, these results suggest that inseminations with $7 \sim 8\left(\times 10^{8}\right)$ spermatozoa would be enough to get high fertility when mare heat condition and insemination technique are good. 